\title{
Respiratory viral infections are underdiagnosed in patients with suspected sepsis
}

\author{
L. R. Ljungström ${ }^{1,3}$ • G. Jacobsson ${ }^{1,3}$ • B. E. B. Claesson ${ }^{2}$ R. Andersson ${ }^{3}$ - H. Enroth E,5 $^{4,}$
}

Received: 26 January 2017 / Accepted: 17 April 2017 / Published online: 17 May 2017

(C) The Author(s) 2017. This article is an open access publication

\begin{abstract}
The study aim was to investigate the prevalence and clinical relevance of viral findings by multiplex PCR from the nasopharynx of clinically septic patients during a winter season. During 11 weeks of the influenza epidemic period in January-March 2012, consecutive adult patients suspected to be septic $(n=432)$ were analyzed with cultures from blood and nasopharynx plus multiplex PCR for respiratory viruses on the nasopharyngeal specimen. The results were compared with those from microbiology analyses ordered as part of standard care. During the winter season, viral respiratory pathogens, mainly influenza A virus, human metapneumovirus, coronavirus, and respiratory syncytial virus were clinically underdiagnosed in $70 \%$ of patients positive by the multiplex PCR assay. During the first four weeks of the influenza epidemic, few tests for influenza were ordered by clinicians, indicating low awareness that the epidemic had started. Nasopharyngeal findings of Streptococcus pneumoniae and
\end{abstract}

Electronic supplementary material The online version of this article (doi:10.1007/s10096-017-2990-z) contains supplementary material, which is available to authorized users.

L. R. Ljungström

lars.ljungstrom@vgregion.se

1 Department of Infectious Diseases, Skaraborg Hospital, 541 85 Skövde, Sweden

2 Department of Clinical Microbiology, Unilabs, Skaraborg Hospital, Skövde, Sweden

3 CARe (Center for Antibiotic Resistance Research), Department of Infectious Diseases, Institute of Biomedicine, Sahlgrenska Academy at Gothenburg University, Gothenburg, Sweden

4 Department of Clinical Molecular Microbiology, Unilabs, Skaraborg Hospital, Skövde, Sweden

5 School of Biosciences, University of Skövde, Skövde, Sweden
Haemophilus influenzae by culture correlated to pneumonia diagnosis, and in those patients laboratory signs of viral coinfections were common but rarely suspected by clinicians. The role of respiratory viral infections in patients presenting with a clinical picture of sepsis is underestimated. Specific antiviral treatment might be beneficial in some cases and may reduce spread in a hospital setting. Diagnosing viral infections may promote reduction of unnecessary antibiotic use. It can also be a tool for decisions concerning patient logistics, in order to minimize exposure of susceptible patients and personnel.

\section{Introduction}

\section{Respiratory tract infections}

The respiratory tract is the most common focus of infection in septic patients. In adults with community-acquired pneumonia (CAP), a bacterial etiology can be established in about 25 $50 \%$ of cases depending on definitions and methods used [1, 2]. S. pneumoniae is the most often found bacteria, followed by $H$. influenzae and Mycoplasma pneumoniae. More rarely found agents are Legionella pneumophila, Chlamydophila pneumoniae, and Coxiella burnetti $[1,3]$. Several respiratory viruses may also cause severe respiratory disease, including CAP, mainly in children, but also in adults. This is well known for influenza A and B viruses, respiratory syncytial virus, coronavirus, human metapneumovirus, parainfluenza viruses types $1-3$, adenovirus, enteroviruses, rhinovirus, and human bocavirus [3-5]. Indeed, viral infections are estimated to cause around 100 million annual cases of CAP worldwide [6]. Many of these viruses have seasonal variation patterns, causing epidemics, often with peaks during winter and early spring [7]. Viral respiratory infections may predispose for bacterial 
infections by damaging the respiratory epithelium as well as by viral-bacterial interactions. For example, influenza A virus can enhance the pathogenicity of $S$. pneumoniae, Staphylococcus aureus or $H$. influenzae. On the other hand it can inhibit the pathogenicity of others, such as M. pneumoniae and $C$. pneumoniae [8-11]. Using molecular techniques it has become evident that viral infection is present in around 25\% of CAP, regardless of severity $[1,12,13]$. Viral co-infections in CAP has been shown to increase both disease severity and length of stay in hospital [14]. In patients with pneumonia requiring intensive care, mixed viral-bacterial infections have demonstrated the highest mortality rate in at least one study [13].

Commercial multiplex tests are continuously being developed, allowing for rapid etiological diagnosis of a wide range of respiratory viruses and bacteria [4, 15-18]. Diagnosing viral respiratory infections may help in reducing admissions, length of stay, use of antibiotic treatment and, in some cases, target antiviral treatment [14]. Testing is optimal during the first days of infection, when the viral load is high [19]. The clinical significance of a viral finding cannot always be determined. Some respiratory viruses, like rhinovirus, can persist in young children up to 6 weeks after a clinical infection [20], though persistence and long-term carriage seems to be less frequent in adults $[1,21]$.

\section{Sepsis}

The definition and criteria for sepsis have changed over the years. Currently, sepsis is defined as a "life-threatening organ dysfunction caused by a dysregulated host response to infection" and said to be present if a patient has an infection and +2 points or more in the SOFA-score [22]. From a clinical viewpoint, a patient is suspected to be septic if there has been a sudden onset of chills and fever accompanied by abnormalities in vital signs, such as an increased respiratory rate, lowered oxygen saturation, tachycardia, hypotension, altered mentation, general malaise, and if laboratory findings such as an increase in leucocytes, C-reactive protein, lactate or procalcitonin support that suspicion. If so, broad-spectrum antibiotic treatment is started on clinical suspicion of bacterial sepsis and according to the preliminary diagnosis. Treatment is later modified according to the results of cultures, other microbiological detection methods, infection biomarkers, and imaging. In most cases, the origin and etiology of the infection cannot be established in the emergency department. Clinical symptoms and signs are helpful but not fully reliable. The inflammatory response in sepsis may itself cause symptoms and signs that can be misleading [23]. For example, a bacteremic urinary tract infection may present with predominating respiratory symptoms and signs [24]. This warrants broad testing early during care.
In this study conducted during the winter season, we pragmatically investigated the clinical relevance of nasopharyngeal viral and bacterial findings from clinically septic patients with suspected respiratory focus or sepsis of unknown origin.

\section{Materials and methods}

\section{The severe sepsis study in Skaraborg}

Over nine months, from September 2011 until June 2012, we performed a prospective, consecutive, epidemiologic study to investigate the incidence of community onset severe sepsis and septic shock in adults in Skaraborg, a rural area in Sweden with a population of 256,000. A single public hospital, Skaraborg Hospital, serves this population. Study inclusion criteria were: residents of Skaraborg 18 years or older who were treated within $48 \mathrm{~h}$ of admission with intravenous antibiotics on clinical suspicion of sepsis. The study was a "real life" study. No formal criteria for sepsis had to be fulfilled. Blood cultures were drawn from all patients before starting antibiotic treatment. Nasopharynx culture was performed on patients with a suspected focus in the respiratory tract or sepsis with unknown focus. Other cultures were done according to the clinical judgment of the treating physician. All patients were evaluated by protocol for the presence or development of severe sepsis or septic shock according to the Swedish definition and criteria [25]. The study was approved by the Regional Ethics Committee in Gothenburg (376-11).

The present study was part of the epidemiological study of severe sepsis, and was carried out during "the flu season" in patients admitted to the hospital from January 19 to March 26. Review of the complete patient records for all patients was performed according to protocol by one infectious diseases specialist (LRL). Clinical relevance was estimated from clinical notes on sudden onset of respiratory symptoms, dry or productive cough, shortness of breath, congestion, fever, imaging showing new infiltrates and when the discharge diagnosis contained a respiratory infection.

\section{Collection of patient samples}

Sampling from the nasopharynx was performed using a flocked swab in universal transport medium (eSwab, Copan) on study patients suspected to be septic and to have a lower respiratory tract infection or sepsis with an unknown focus. Results obtained from this swab are comparable to those from nasopharyngeal aspirate [26]. Specimens were used for traditional NP-culture according to conventional methods and then stored at $-20{ }^{\circ} \mathrm{C}$. The samples were plated within $24 \mathrm{~h}$ after collection and plates were read after 24 and $48 \mathrm{~h}$ incubation. Target organisms were S. pneumoniae, H. influenzae, M. catarrhalis, beta-hemolytic streptococci groups $\mathrm{A}, \mathrm{C}$, and 
G. Growth of other species were reported only when observed in pure culture. All stored samples were analyzed within three months using either of two different viral respiratory multiplex PCR tests (Fig. 1).

Two sets of blood cultures (BacT/Alert, BioMerieux) were drawn from each patient before initiation of intravenous antibiotic treatment.

\section{Routine PCR analysis of respiratory infections}

A separate flocked nasopharyngeal swab (eSwab, Copan) was used for routine testing of influenza $\mathrm{A}$ and $\mathrm{B}$ viruses, respiratory syncytial virus (triple viral test) and M. pneumoniae and collected at the discretion of the treating physician. These swabs were transported in $1 \mathrm{~mL} \mathrm{NaCl}$ and used for in-house PCR tests. Results from the triple viral PCR tests were reported within a few hours but also used for comparison with the results obtained later from the samples collected and analyzed with the commercial tests (see below) as part of this study. Analysis of $M$. pneumoniae was performed on the nasopharyngeal samples by a probe-based lab-developed real-time PCR detecting the adhesin gene of $M$. pneumoniae. This PCR assay was run, analyzed, and interpreted on the Rotorgene instrument (Qiagen).

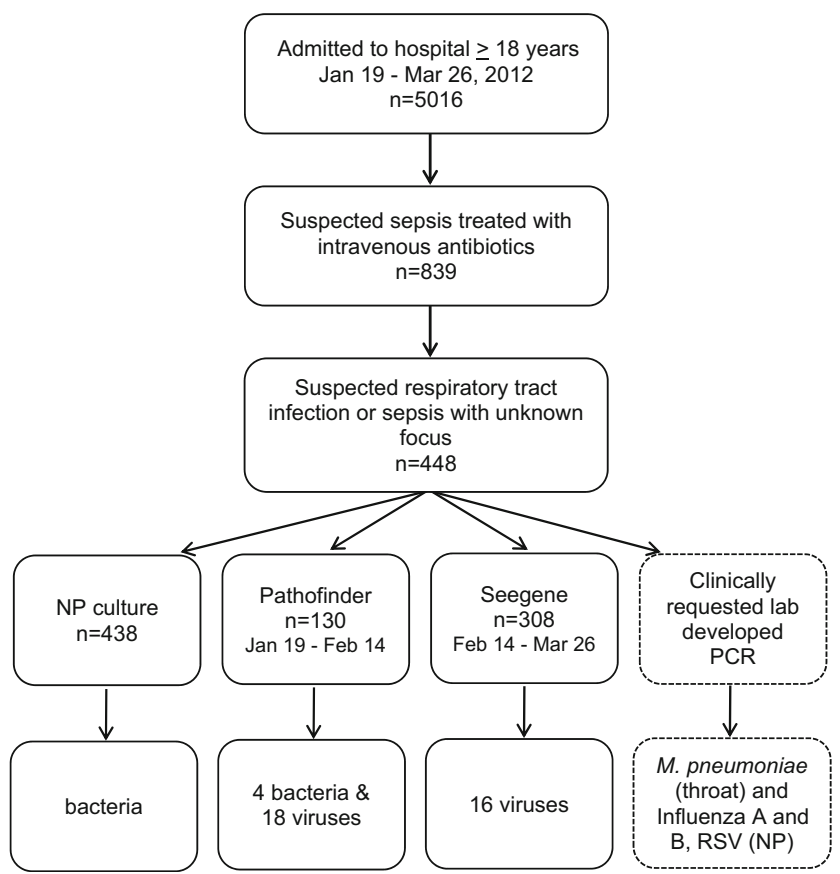

Fig. 1 Out of 5,016 patients admitted to the hospital during the study period, $839(16 \%)$ were treated with intravenous antibiotics on suspicion of sepsis. Around $50 \%$ of them were suspected to have a respiratory focus or an unknown focus of infection, sampled from the nasopharynx, and included in the study. Two different multiplex PCR tests were used for the study patients. In clinical use for all patients during the study period was a lab-developed PCR for influenza A and B virus and respiratory syncytial virus (triple test) as well as a lab-developed PCR for $M$. pneumoniae detection. $R S V$ respiratory syncytial virus, $N P$ nasopharynx

\section{Nucleic acid extraction}

Nasopharyngeal samples from the original tubes were prepipetted to 96-plates in a Microlab Starlet (Hamilton Robotics, Switzerland) before extraction. Total nucleic acid extraction was performed with the MagNA Pure 96 instrument (Roche Applied Science) using the DNA and Viral NA small volume kit, the protocol Pathogen Universal, sample volume $300 \mu \mathrm{L}$ and elution volume $100 \mu \mathrm{L}$ [20]. Samples of extracted nucleic acids were mixed into the PCR reagents with a Qiagility (Qiagen, Hilden, Germany).

\section{Real-time multiplex PCR for respiratory viruses}

An analysis of samples collected during the winter can be found in Fig. 1. From January 19 to February $14(n=130)$, a broad-spectrum commercial multiplex real-time PCR assay detecting 18 viruses and four bacteria was used (Respifinder SMART 22 kit, Pathofinder, Netherlands) [21]. Respifinder is designed to detect respiratory syncytial virus types $\mathrm{A}$ and $\mathrm{B}$, adenovirus, human metapneumovirus, influenza A and B viruses, rhinovirus, enteroviruses, parainfluenza viruses types 14, human bocavirus, coronavirus types NL63, HKU1, 229E, and OC43, M. pneumoniae, L. pneumophila, Bordetella pertussis, and C. pneumoniae. This PCR assay was run, analyzed and interpreted on the Rotorgene instrument (Qiagen). One sample gave no results and was excluded from the study. In total, 129 multiplex results were used for the final analysis.

Samples collected from February 15 to March $26(n=308)$ were analyzed by a commercial multiplex real-time PCR assay detecting 16 respiratory viruses (Anyplex II RV 16, Seegene, Korea). This kit detects respiratory syncytial virus types A and B, adenovirus, human metapneumovirus, influenza A and B viruses, rhinovirus, enteroviruses, parainfluenza viruses types 1-4, human bocavirus, and coronavirus types NL63, 229E, and OC43 [22]. This PCR assay was run on the CFX96 Real-time PCR system (BioRad, France) and was analyzed and interpreted using "Seegene viewer" software (Seegene). Five samples were invalid and were excluded, leaving 303 results by the Anyplex II PCR for the final analysis. In total, 432 clinical NP samples were analyzed by multiplex PCR.

\section{Definition of pneumonia and respiratory tract infection}

The Swedish Infectious Disease Society national guidelines define pneumonia as "symptoms or signs consistent with acute lower respiratory infection in combination with radiological findings compatible with this disease" (updated 2016, online and in Swedish only). A diagnosis of pneumonia in this study was made if there were symptoms or signs consistent with acute lower respiratory infection, and a finding within the first $48 \mathrm{~h}$ of a new infiltrate by chest X-ray or CT scan, and if 
no alternative diagnosis accounting for the new infiltrate was made during the stay in hospital. A diagnosis of respiratory tract infection was made if there were symptoms or signs consistent with acute respiratory infection but no X-ray findings compatible with pneumonia or if no imaging was performed and if there was no other explanation for the symptoms during the stay in hospital.

\section{Results}

A total of 5,016 patients were admitted to the hospital during the study period. The average age was 71 years and $50.1 \%$ were men. Out of those admitted, $839(16.7 \%)$ received intravenous antibiotic treatment within $48 \mathrm{~h}$ and were included in the larger epidemiological sepsis study. The average age was 69 years and $54.5 \%$ were men. From 438 out of 839 (52.2\%) patients a nasopharyngeal swab was collected and 432 could be evaluated by both culture and multiplex PCR for bacteria or respiratory viruses.

\section{Nasopharyngeal findings by real-time multiplex PCR}

Multiplex PCR testing detected 166 viruses in 158 of 432 patients (37\%) (Table 1) of whom $60 \%$ were men, with an average age of 70 years, and $40 \%$ were women, average age 73 years. No influenza B virus was found in study samples. Two samples positive for influenza A virus by routine testing could not be confirmed by multiplex PCR.

Table 1 Findings in nasopharyngeal swabs by multiplex PCR from 432 patients with suspected sepsis

\begin{tabular}{lll}
\hline Pathogen & $\begin{array}{l}\text { Number } \\
\text { of findings }\end{array}$ & $\begin{array}{l}\text { Percent of } \\
\text { total }(\%)\end{array}$ \\
\hline Influenza A virus & 96 & 22 \\
Human metapneumovirus & 23 & 5 \\
Coronavirus types OC43, 229E, and HKU1 & $19(14,2,3)$ & 4 \\
Respiratory syncytial virus types A and B & $12(6,6)$ & 3 \\
Rhinovirus and enteroviruses & 10 & 2 \\
Parainfluenza viruses types 1, 2, 3, and 4 & $3(2,1)$ & 0.6 \\
Human bocavirus & 2 & 0.4 \\
Adenovirus & 1 & 0.2 \\
Mycoplasma pneumoniae & 5 & 1 \\
Total & 171 & \\
\hline
\end{tabular}

In a study of 432 patients with suspected sepsis during the winter season in 2012, 166 viruses were found in 158 patients by multiplex PCR on specimens from the nasopharynx. In eight patients there were double findings, six including influenza A virus, three including human metapneumovirus and one including respiratory syncytial virus. Out of the first 129 patients tested by the Pathofinder multiplex PCR, five were positive for M. pneumoniae
Influenza A virus was the most common finding, detected in $96 / 158(61 \%)$ of study patients. During the same period, clinicians ordered the triple viral test for influenza A and B viruses and respiratory syncytial virus in 308 patients. Of those, $126(41 \%)$ were positive for influenza A virus, 1 $(0.3 \%)$ for influenza B virus and 7 (2\%) for respiratory syncytial virus. During the first three study weeks, only one clinically requested test was positive for influenza A virus compared with six in the study group. During the first four weeks of the influenza epidemic there were few clinically requested tests for influenza virus. This indicates that early in the influenza epidemic, awareness among clinicians that the flu season had started was low (Fig. 2). The routine triple viral test for influenza A and B viruses and respiratory syncytial virus available to clinicians was requested in only 56 of 107 (54\%) patients who turned out positive for those viruses in the study analysis.

The Pathofinder multiplex PCR used for the first 129 patients of the study was positive for M. pneumoniae in five cases. Two of these patients also tested positive in the clinically available test. During the latter part of the study, when PCR for M. pneumoniae was not included in the multiplex PCR, there was one additional patient positive for M. pneumoniae by routine PCR testing.

\section{Nasopharyngeal findings by culture}

By conventional culture from the nasopharynx culture there were 101 out of 432 (23.4\%) patients positive for any bacteria (Table 2).

\section{Mixed bacterial and virological findings}

In total, 50 of $432(12 \%)$ patients were positive for both a respiratory virus and bacteria. The bacteria most often associated with a viral respiratory pathogen were $S$. pneumoniae in 14 of 50 (28\%), M. catarrhalis in $14(28 \%), S$. aureus in 7 $(14 \%)$ and $H$. influenzae in $6(12 \%)$. The most frequently found viruses were influenza A virus in 27 (54\%), human metapneumovirus in 10 (20\%), and respiratory syncytial virus in $4(8 \%)$. S. pneumoniae was found together with a virus in 14 of 19 samples, H. influenzae in 6 of 17, M. catarrhalis in 14 of 28 and Staphylococcus aureus in 7 of 14 (Table 3).

\section{Blood cultures}

Two sets of blood cultures were drawn before initiation of intravenous antibiotic treatment in all 432 patients. Of those, 35 patients $(8 \%)$ were positive for a true bacterial pathogen [27]. The bacterial species were $S$. aureus $(n=12), E$. coli $(\mathrm{n}=8)$, S. pneumoniae $(n=5)$, Klebsiella pneumoniae $(n=4)$, $S$. pyogenes $(n=2)$, and others species in four patients. In the 
Fig. 2 Results for influenza A virus testing between January 19 and March 26, 2012. Samples from study patients with suspected sepsis are compared with all clinically requested samples for influenza A virus in all hospitalized patients. There were very few clinical requests (C) for influenza A virus testing during the first four weeks of the de facto influenza season, indicating a lack of systemic awareness and clinical suspicion even during a rapid escalation in cases
INFLUENZA A VIRUS STUDY SAMPLES (S) COMPARED WITH CLINICAL SAMPLES (C)

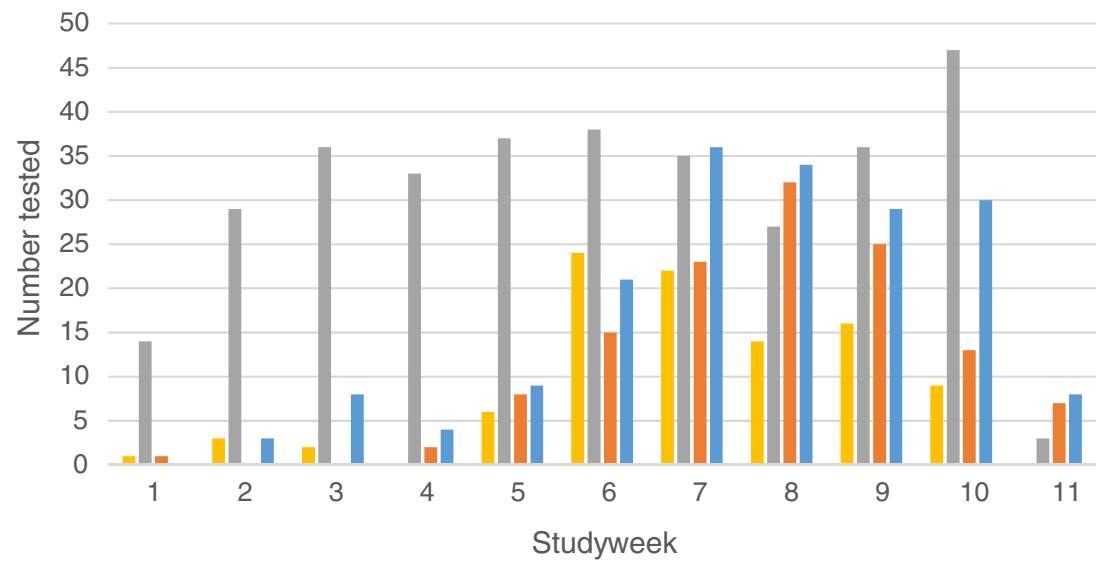

(S) Influenza A pos $\square($ (S) Influenza A neg $\square(C)$ Influenza A pos $\square(C)$ Influenza A neg overall nine-month epidemiological study, 313 of 2,472 $(12.6 \%)$ blood cultures were positive for a true pathogen.

\section{Clinical diagnoses in patients with suspected sepsis and microbial findings in the nasopharynx}

Of the 158 patients with a finding of one or two respiratory viruses, the respiratory tract was the initially suspected focus of infection in $70 \%$. In $18 \%$ it was sepsis with unknown focus, and in $12 \%$ it was some other focus (Table 4 ).

Table 2 Bacterial findings in nasopharyngeal swabs by culture and multiplex PCR from 432 patients with suspected sepsis

\begin{tabular}{lll}
\hline Bacteria & $\begin{array}{l}\text { Number of } \\
\text { findings }\end{array}$ & $\begin{array}{l}\text { Percent (\%) } \\
\text { of findings }\end{array}$ \\
\hline S. pneumoniae & 19 & 17 \\
H. influenzae & 18 & 16 \\
M. catarrhalis & 31 & 28 \\
S. aureus & 14 & 11 \\
S. pyogenes(3) and dysgalactiae(2) & 5 & 5 \\
Enterobacteriacae & 5 & 5 \\
N. meningitidis & 2 & 2 \\
Corynebacterium liquefaciens/propinquum & 8 & 7 \\
Other & 2 & 2 \\
M. pneumoniae (by multiplex PCR) & 5 & 5 \\
Total & 109 & \\
\hline
\end{tabular}

In a study of 432 patients with suspected sepsis during the winter season in 2012, 109 bacteria were found in the nasopharynx in 104 patients. Culture diagnosed 104 of those. The Pathofinder multiplex PCR was used for the first 129 of 432 patients revealed five cases of M. pneumoniae. In five cultures there were double bacterial findings. Three had $H$. influenzae and $M$. catarrhalis. Two positive for $M$. pneumoniae by multiplex-PCR also had $H$. influenzae and $N$. meningitidis, respectively
According to the patient records, there was an initial clinical suspicion of a respiratory viral infection as part of the clinical picture in only $30 \%$ of the cases, even though the study occurred well into the known influenza season. In the emergency department, only $36 \%$ of all study patients positive for influenza A virus were initially suspected to have "influenza" or "virosis". During the time in hospital, another $18 \%$, altogether $54 \%$, were clinically suspected to have influenza and were tested by routine analysis. Out of 33 patients positive for either human metapneumovirus or respiratory syncytial virus, only $35 \%$ were clinically tested on suspicion of a viral infection. Yet, in the patient records, respiratory symptoms were documented in as many as 87 of $96(90 \%)$ patients positive for influenza A virus and in all 33 positive for human metapneumovirus or respiratory syncytial virus. Only in 9 of 96 patients with fever testing positive for influenza A virus, there was no documentation of respiratory tract symptoms. Findings of rhinovirus, enteroviruses, coronavirus or human bocavirus were less often linked to respiratory disease, and more often found in patients with infections outside the respiratory tract, or with no infection at all (Table 3).

Out of 158 patients positive for any viral agent, 17 fulfilled at least one of the Swedish criteria for severe sepsis or septic shock. Fourteen of those were in the group with a new pulmonary infiltrate.

Bacterial findings of $M$. pneumoniae $(n=5)$,S. pneumoniae $(n=19)$ and $H$. influenzae $(n=18)$ correlated to pneumonia in 39 of $41(95 \%)$ cases. One patient positive for $H$. influenzae had a co-infection with $M$. pneumoniae, suffered from severe sepsis, and died after one day in the ICU. Another positive for M. pneumoniae was co-infected with Neisseria meningitidis and had a clinically mild course. Findings of $M$. catarrhalis, $S$. aureus (no MRSA), Enterobacteriaceae spp., beta-hemolytic 
Table 3 Correlation between results by culture and multiplex PCR in the nasopharynx to final diagnosis in adult patients $(n)$ suspected to have sepsis

\begin{tabular}{|c|c|c|c|c|}
\hline Agent & & Final diagnosi & & \\
\hline $\begin{array}{l}\text { Culture } \\
\mathrm{n}=101\end{array}$ & $\begin{array}{l}\text { Multiplex PCR } \\
\mathrm{n}=163 \\
\text { (six had two } \\
\text { viruses) }\end{array}$ & $\begin{array}{l}\text { Pneumonia } \\
\mathrm{n}=137\end{array}$ & $\begin{array}{l}\text { Respiratory } \\
\text { tract } \\
\text { infection } \\
\mathrm{n}=85\end{array}$ & $\begin{array}{l}\text { Other or no } \\
\text { infection } \\
n=210\end{array}$ \\
\hline $\begin{array}{l}S . \\
\text { pneumoniae } \\
\mathrm{n}=19\end{array}$ & $\begin{array}{l}\text { Influenza A } \\
\text { virus } n=8 \\
\text { hMPV } n=5 \\
\text { RSV } n=0 \\
\text { Other } n=1 \\
\text { No virus } n=5\end{array}$ & $\begin{array}{l}8 / 8(100 \%) \\
\\
5 / 5(100 \%) \\
- \\
1 / 1(100 \%) \\
5 / 5(100 \%)\end{array}$ & $-0 / 19$ & $\zeta \quad 0 / 19$ \\
\hline $\begin{array}{l}\text { H. influenzae } \\
\mathrm{n}=18 \\
\text { (three also } \\
\text { cultured } M \text {. } \\
\text { catarrhalis) }\end{array}$ & $\begin{array}{l}\text { Influenza A } \\
\text { virus } \mathrm{n}=3 \\
\mathrm{hMPV} \mathrm{n}=2 \\
\mathrm{RSV} \mathrm{n}=0 \\
\text { Other } \mathrm{n}=1 \\
\text { No virus } \mathrm{n}=11 \\
\text { M. } \\
\text { pneumoniae } \\
\mathrm{n}=1\end{array}$ & $\begin{array}{l}3 / 3(100 \%) \\
2 / 2(100 \%) \\
- \\
1 / 1(100 \%) \\
9 / 11(82 \%) \\
1 / 1(100 \%)\end{array}$ & $\int_{-}^{J_{2} / 1} 0 / 6$ & $0 / 18$ \\
\hline $\begin{array}{l}\text { M. } \\
\text { catarrhalis } \\
\mathrm{n}=28\end{array}$ & $\begin{array}{l}\text { Influenza A } \\
\text { virus } n=8 \\
\text { hMPV } n=2 \\
\text { RSV } n=1 \\
\text { Other } n=3 \\
\text { No virus } n=14\end{array}$ & $\begin{array}{l}2 / 8 \\
- \\
1 / 1 \\
2 / 3 \\
3 / 14\end{array}$ & $\begin{array}{l}4 / 8 \\
1 / 2 \\
- \\
- \\
6 / 14\end{array}$ & $\begin{array}{l}2 / 8 \\
1 / 2 \\
- \\
1 / 3 \\
5 / 14\end{array}$ \\
\hline $\begin{array}{l}\text { S. aureus } \\
\mathrm{n}=14\end{array}$ & $\begin{array}{l}\text { Influenza A } \\
\text { virus } n=3 \\
\text { hMPV } n=1 \\
\text { RSV } n=1 \\
\text { Other } n=2 \\
\text { No virus } n=7\end{array}$ & $\begin{array}{l}- \\
- \\
- \\
- \\
2 / 7\end{array}$ & $\begin{array}{l}1 / 3 \\
1 / 1 \\
1 / 1 \\
1 / 2 \\
-\end{array}$ & $\begin{array}{l}2 / 3 \\
- \\
- \\
1 / 2 \\
5 / 7\end{array}$ \\
\hline $\begin{array}{l}\text { Other } \\
\text { bacteria } \\
\mathrm{n}=22\end{array}$ & $\begin{array}{l}\text { Influenza A } \\
\text { virus } \mathrm{n}=5 \\
\mathrm{hMPV} \mathrm{n}=0 \\
\text { RSV } \mathrm{n}=1 \\
\text { Other } \mathrm{n}=2 \\
\text { No virus } \mathrm{n}=13 \\
\begin{array}{l}\text { M. } \\
\text { pneumoniae } \\
\mathrm{n}=1\end{array}\end{array}$ & $\begin{array}{l}1 / 5 \\
- \\
- \\
2 / 2 \\
2 / 2 \\
1 / 1\end{array}$ & $\begin{array}{l}4 / 5 \\
- \\
- \\
- \\
- \\
-\end{array}$ & $\begin{array}{l}- \\
- \\
1 / 1 \\
- \\
11 / 13 \\
-\end{array}$ \\
\hline $\begin{array}{l}\text { Culture } \\
\text { negative } \\
n=331\end{array}$ & $\begin{array}{l}\text { Influenza A } \\
\text { virus } \mathrm{n}=69 \\
\mathrm{hMPV} \mathrm{n}=12 \\
\text { RSV } \mathrm{n}=8 \\
\text { Other } \mathrm{n}=20 \\
\text { No virus } \\
\mathrm{n}=219 \\
\text { M. } \\
\text { pneumoniae } \\
\mathrm{n}=3\end{array}$ & $\begin{array}{l}\text { 26/69 (38\%) } \\
\text { 5/12 (42\%) } \\
\mathbf{3 / 8}(38 \%) \\
\mathbf{4} / 20(20 \%) \\
45 / 219 \\
3 / 3(100 \%)\end{array}$ & $\begin{array}{l}34 / 69 \\
4 / 12 \\
4 / 8 \\
2 / 20 \\
20 / 219 \\
\\
0 / 3\end{array}$ & $\begin{array}{l}9 / 69 \\
3 / 12 \\
1 / 8 \\
14 / 20 \\
154 / 219 \\
0 / 3\end{array}$ \\
\hline
\end{tabular}

During the winter season in 2012,432 patients with suspected sepsis were tested from the nasopharynx by culture and multiplex PCR for respiratory viruses. Finding of $S$. pneumoniae or $H$. influenzae strongly correlated to pneumonia. In $75 \%$ of patients with $S$. pneumoniae there was also a viral finding, mainly influenza A virus and human metapneumovirus. Apart from the viral findings, the Pathofinder Multiplex PCR test detected five cases of M. pneumoniae. All five had pneumonia. One also grew H. influenzae and had a rapidly fatal course. One also grew Neisseria meningitidis and had a mild course

$h M P V=$ human metapneumovirus; $R S V=$ respiratory syncytial virus types $\mathrm{A}$ and $\mathrm{B}$ 
Table 4 Initially suspected focus of infection in 158 septic patients with viral findings in the nasopharynx by multiplex PCR

\begin{tabular}{|c|c|c|c|c|c|}
\hline \multirow[t]{2}{*}{ Virus $(\mathrm{N}=158)$} & \multicolumn{3}{|c|}{ Initially suspected focus ( $n$ ) } & \multirow{2}{*}{$\begin{array}{l}\text { Suspected focus other } \\
\text { than the respiratory } \\
\text { tract, } n(\%)\end{array}$} & \multirow{2}{*}{$\begin{array}{l}\text { Initial clinical suspicion } \\
\text { of "influenza" } \\
\text { or "virosis", } n(\%)\end{array}$} \\
\hline & Respiratory tract, $n(\%)$ & Sepsis UNS, $n(\%)$ & Other, $n(\%)$ & & \\
\hline Influenza A virus, $n=96$ & 79 & 13 & 4 & $17(18)$ & $\begin{array}{l}35 / 96 \\
(36)\end{array}$ \\
\hline Human metapneumovirus, $n=22$ & 14 & 7 & 1 & $8(36)$ & $\begin{array}{l}5 / 22 \\
(23)\end{array}$ \\
\hline Respiratory syncytial virus, $n=11$ & 8 & 1 & 2 & $3(27)$ & $\begin{array}{l}3 / 11 \\
(27)\end{array}$ \\
\hline Coronavirus, $n=16$ & 6 & 3 & 7 & $10(63)$ & $1 / 16(6)$ \\
\hline Rhinovirus or enteroviruses, $n=9$ & 3 & 4 & 2 & $6(67)$ & $0 / 9(0)$ \\
\hline Other, $n=4$ & 1 & - & 3 & $3(75)$ & $1 / 4(25)$ \\
\hline Total, $n=158$ & $\begin{array}{l}111 / 158 \\
(70)\end{array}$ & 28/158 (18) & $19 / 158(12)$ & $\begin{array}{l}47 / 158 \\
(30)\end{array}$ & $\begin{array}{l}45 / 158 \\
(30)\end{array}$ \\
\hline
\end{tabular}

Despite being in the winter season, a viral etiology or co-etiology was initially considered in only $30 \%$ of the patients with suspected sepsis. In $30 \%$ the initial focus of the infection was believed to be some other than the respiratory tract, mainly "Sepsis with unknown focus". Eight patients had double viral findings. Six were found together with influenza A virus and were counted as influenza A virus. Two were found together with human metapneumovirus and were counted as human metapneumovirus

streptococci groups A, C, or G, or other bacteria, were less often associated with pneumonia.

Pneumonia, as indicated by a new infiltrate on chest X-ray or CT scan, was demonstrated in 137 of 432 study patients, with a median age of 73 years, whereby $55 \%$ were men. In another eight patients it could not be determined whether there was a new infiltrate, and in 28 patients no chest X-ray was performed. In patients with pneumonia, 91 of 137 were positive in the nasopharynx for some respiratory virus or bacteria. The most common agents were influenza A virus $(n=40)$, $S$. pneumoniae $(n=19), H$. influenzae $(n=16)$, human metapneumovirus $(n=12), M$. pneumoniae $(n=5)$, and respiratory syncytial virus types A or B $(n=4)$. In 22 patients there was a co-finding of any of those bacteria plus any of those viruses and in one patient there was a co-finding of H. influenzae and M. pneumoniae (Table 3).

\section{Discussion}

We found that viral infections were often neglected during this population-based "real life" study of suspected septic patients. The study was performed during the winter period, referred to as "the flu season", when respiratory viral infections are most prevalent. This should have resulted in increased clinical suspicion. Yet, during the first four weeks of the influenza epidemic, very few clinical samples are requested. In this material, a viral respiratory infection was initially suspected by clinicians in only $30 \%$ of patients with viral findings by multiplex PCR. This was especially true when CRP was over $100 \mathrm{mg} / \mathrm{L}$, or if there was a new infiltrate on the chest X-ray indicating pneumonia. This underestimation may lead to nosocomial spread or outbreaks of viral respiratory infections, as we have previously experienced in our own hospital. It may also lead to overuse of antibiotics, as well as underuse of antivirals, especially in risk groups that might benefit from such treatment.

As in a comprehensive study on bacterial-viral respiratory tract illness over three winter seasons by Falsey et al. in 2013 [28], influenza A virus was the most common viral finding, appearing in study samples almost two weeks earlier than in clinical samples. In only 35 of 96 cases of influenza A virus infection $(36 \%)$ was influenza virus initially suspected as sole cause or contributing factor to the acute illness.

Respiratory syncytial virus and human metapneumovirus may cause critical respiratory illness and pneumonia, not only in children, but also in elderly. For example, human metapneumovirus was found to be the causative agent in an outbreak of pneumonia among elderly at an institution in the Netherlands [29]. In this study, human metapneumovirus was a slightly more common finding than respiratory syncytial virus, especially in patients with long history of fever and respiratory tract congestion, combined with radiological signs of pneumonia.

Nasopharyngeal culture is generally discouraged or not recommended for etiological diagnosis of pneumonia. However, in a Swedish study by Strålin et al. in 2006 [30], there was a good correlation between nasopharyngeal findings of these bacteria and the etiology of pneumonia, as has been seen in previous Swedish studies. In our study of patients in the emergency department suspected to be septic, there was a strong correlation between nasopharyngeal findings of $S$. pneumoniae or $H$. influenzae and X-ray findings of a new infiltrate, indicative of pneumonia. More so, these bacteria 
were not found in the nasopharynx of any of the 210 patients with a non-respiratory infection or no infection, and they were rarely found in patients with a respiratory tract infection but not pneumonia. The study results imply that nasopharyngeal findings of S. pneumoniae and $H$. influenzae in sepsis patients should be considered carefully for patient treatment. A recently published paper by Bjarnason et al. in 2017 [31] demonstrates a good correlation between real-time PCR findings of $S$. pneumoniae or $H$. influenzae to pneumonia diagnosis in adults, which also builds support for a clinical relevance of these upper respiratory bacterial findings.

Co-infections of bacteria and respiratory viruses, mainly S. pneumoniae and influenza A or respiratory syncytial virus, are found in $3-40 \%$ of patients with CAP, depending on diagnostic methods used, with the higher end reflecting studies in which nasopharyngeal culture is included for etiological diagnosis $[1,2]$. Using nasopharyngeal sampling only, we found indications of viral-bacterial co-infections in 28 of 137 (20\%), a proportion we believe to be an underestimation. As in the study by Falsey et al. in 2013 [28], $S$. pneumoniae was the bacteria most often associated with pneumonia and a viral co-infection. As many as $75 \%$ of patients with pneumonia and $S$. pneumoniae in the nasopharynx were positive for a respiratory virus, mainly influenza A virus, but also human metapneumovirus. The two youngest patients, with pneumonia and severe sepsis, aged 37 and 42 years respectively, were both positive for S. pneumoniae and human metapneumovirus in the nasopharynx. No other pathogens could be demonstrated by routine cultures.

In the clinical setting it is often difficult to determine whether a patient with respiratory symptoms has a viral infection, a bacterial infection, or a mixed viral-bacterial infection. No constellation of clinical symptoms, vital signs, biomarkers (such as white blood cell count, C-reactive protein, or procalcitonin) have adequate sensitivity and specificity. New tools to improve predictions of patient benefit from antibiotic treatment are urgently needed. Recently, whole blood analysis for the identification of host gene activation profiles has been able to discriminate viral infections from bacterial infections with high accuracy in severely ill infants, as described by Herberg et al. in 2016 [32]. In adults with lower respiratory tract infections, a similar technique seems able to discriminate viral from bacterial infections much better than procalcitonin, as shown by Suarez et al. in 2015 [33]. In the same study mixed viral-bacterial infections also elicited a characteristic gene activation profile.

Our study supports increased testing for respiratory viruses in patients believed to be septic, especially those presenting with respiratory tract symptoms. With current technology, results can be obtained within a few hours and have an impact on clinical decisions and patient logistics in the emergency department. Cost effectiveness should be investigated. A viral diagnosis may not only lead to fewer admissions and less antibiotic treatment if bacterial pneumonia is suspected or demonstrated, but may also decrease viral exposures for admitted patients. Patients with influenza A or B may benefit from antiviral treatment alone or in conjunction with antibacterial treatment, if bacterial pneumonia is suspected or demonstrated, perhaps even reducing viral contagiousness. Even in neutropenic patients, a viral finding and a favorable outcome in the first few days may safely allow for discontinuation of antibiotic treatment [34].

This study has several limitations. It is a single-center study performed during one winter period only. The study was primarily not an etiological study of respiratory tract infections. We did not take ongoing antibiotic treatment into account. Only routine sampling from the nasopharynx was performed, albeit using a flocked swab for better yield. If sputum or nasopharyngeal aspirates had been analyzed with molecular techniques, we would have expected a higher yield for both bacteria and viruses [2, 30]. A further weakness is the open inclusion based on clinical suspicion of sepsis only, without specific criteria. Yet another was the subjectivity involved in deciding the relevance of the findings. What role do the viral findings play, both alone or in conjunction with bacterial findings? We can only show correlations between findings and clinical entities, yet the majority of findings do seem to correlate well to respiratory tract infections. Therefore, we believe that our conclusion, that significant viral disease in severely ill patients is underdiagnosed by clinicians, is warranted. Diagnosing these infections early may be of help for the clinical decision making process and thereby for the patients.

\section{Conclusion}

We found that viral respiratory pathogens were underdiagnosed in severely ill patients suspected to be septic, many presenting with clinical symptoms from the respiratory tract. This may lead to nosocomial spread of viral respiratory infections, unnecessary use of antibiotics and underuse of antivirals in the hospital setting.

Furthermore, we found a correlation between nasopharyngeal findings of $S$. pneumoniae or $H$. influenzae and pneumonia in patients with suspected sepsis. Though sensitivity is low, specificity is high. In light of disease severity and low analysis cost, this study can support the use of admission nasopharyngeal culture as part of diagnostic bundles for sepsis patients. An extended use of molecular tests could improve diagnosis, patient care and clinical outcome in patients with suspicion of sepsis, while decreasing risk for nosocomial infections. 
Acknowledgements We thank the staff at Skaraborg Hospital in Skövde and Lidköping and the laboratory personnel at Unilabs for skilful assistance during the collection of the study. We thank Jesper Karlsson who did all the multiplex-PCR testing. We also thank Prof. Lars Hagberg, and Dr. Michael Toepfer for reviewing the whole manuscript. Finally, we greatly appreciate Mrs. Anna-Lena Emanuelsson-Loft for scrutinizing the lay-out of the article. This study was supported by grants from regional funds in Västra Götaland, clinical research fund Skaraborg Hospital, and from Unilabs R\&D fund.

\section{Compliance with ethical standards}

Conflict of interest The authors declare no conflicts of interest in relation to this study.

Ethical approval The study was approved by the Regional Ethics Committee in Gothenburg (376-11). All patients or a close relative received oral and written information about the epidemiological sepsis study. Initial sampling done as part of standard medical care, such as blood culture or culture from the respiratory tract when clinically indicated, did not require individual consent.

Informed consent Informed consent was waived because of the observational nature of the study.

Open Access This article is distributed under the terms of the Creative Commons Attribution 4.0 International License (http:// creativecommons.org/licenses/by/4.0/), which permits unrestricted use, distribution, and reproduction in any medium, provided you give appropriate credit to the original author(s) and the source, provide a link to the Creative Commons license, and indicate if changes were made.

\section{References}

1. Jain S, Self WH, Wunderink RG, Fakhran S, Balk R, Bramley AM, Reed C, Grijalva CG, Anderson EJ, Courtney DM, Chappell JD, Qi C, Hart EM, Carroll F, Trabue C, Donnelly HK, Williams DJ, Zhu Y, Arnold SR, Ampofo K, Waterer GW, Levine M, Lindstrom S, Winchell JM, Katz JM, Erdman D, Schneider E, Hicks LA, McCullers JA, Pavia AT, Edwards KM, Finelli L (2015) Community-acquired pneumonia requiring hospitalization among U.S. adults. N Engl J Med 373(5):415-427

2. Johansson N, Kalin M, Tiveljung-Lindell A, Giske CG, Hedlund J (2010) Etiology of community-acquired pneumonia: increased microbiological yield with new diagnostic methods. Clin Infect Dis 50(2):202-209

3. Cillóniz C, Ewig S, Polverino E, Marcos MA, Esquinas C, Gabarrús A, Mensa J, Torres A (2011) Microbial aetiology of community-acquired pneumonia and its relation to severity. Thorax 66(4):340-346

4. Mahony JB, Petrich A, Smieja M (2011) Molecular diagnosis of respiratory virus infections. Crit Rev Clin Lab Sci 48(5-6):217-249

5. Johansson N, Kalin M, Hedlund J (2011) Clinical impact of combined viral and bacterial infection in patients with communityacquired pneumonia. Scand J Infect Dis 43(8):609-615

6. Ruuskanen O, Lahti E, Jennings LC, Murdoch DR (2011) Viral pneumonia. Lancet 377(9773):1264-1275

7. Brittain-Long R, Andersson L-M, Olofsson S, Lindh M, Westin J (2012) Seasonal variations of 15 respiratory agents illustrated by the application of a multiplex polymerase chain reaction assay. Scand $\mathrm{J}$ Infect Dis 44(1):9-17
8. Smith CM, Sandrini S, Datta S, Freestone P, Shafeeq S, Radhakrishnan P, Williams G, Glenn SM, Kuipers OP, Hirst RA (2014) Respiratory syncytial virus increases the virulence of Streptococcus Pneumoniae by binding to penicillin binding protein 1a. A new paradigm in respiratory infection. Am J Respir Crit Care Med 190(2):196-207

9. Wolf AI, Strauman MC, Mozdzanowska K, Whittle JR, Williams KL, Sharpe AH, Weiser JN, Caton AJ, Hensley SE, Erikson J (2014) Coinfection with Streptococcus Pneumoniae modulates the B cell response to influenza virus. J Virol 88(20):11995-12005

10. Lee KH, Gordon A, Foxman B (2016) The role of respiratory viruses in the etiology of bacterial pneumonia an ecological perspective. Evol Med Public Health 2016(1):95-109

11. Mina M, Burke R, Klugman K (2014) Estimating the prevalence of coinfection with influenza virus and the atypical bacteria Bordetella pertussis, Chlamydophila pneumoniae, and Mycoplasma pneumoniae. Eur J Clin Microbiol Infect Dis 33(9):1585-1589

12. Burk M, El-Kersh K, Saad M, Wiemken T, Ramirez J, Cavallazzi R (2016) Viral infection in community-acquired pneumonia: a systematic review and meta-analysis. Eur Respir Rev 25(140):178188

13. Voiriot G, Visseaux B, Cohen J, Nguyen LBL, Neuville M, Morbieu C, Burdet C, Radjou A, Lescure F-X, Smonig R (2016) Viral-bacterial coinfection affects the presentation and alters the prognosis of severe community-acquired pneumonia. Crit Care 20(1):375

14. Rappo U, Schuetz AN, Jenkins SG, Calfee DP, Walsh TJ, Wells MT, Hollenberg JP, Glesby MJ (2016) Impact of early detection of respiratory viruses by multiplex PCR on clinical outcomes in adult patients. J Clin Microbiol: JCM. doi:10.1128/JCM.00549-16

15. Reddington K, Tuite N, Barry T, O'Grady J, Zumla A (2013) Advances in multiparametric molecular diagnostics technologies for respiratory tract infections. Curr Opin Pulm Med 19(3):298-304

16. Esposito S, Principi N (2017) The role of the NxTAG® respiratory pathogen panel assay and other multiplex platforms in clinical practice. Exp Rev Mol Diagn 17(1):9-17

17. Andersson ME, Olofsson S, Lindh M (2014) Comparison of the FilmArray assay and in-house real-time PCR for detection of respiratory infection. Scand J Infect Dis 46(12):897-901

18. Green DA, Hitoaliaj L, Kotansky B, Campbell SM, Peaper DR (2016) Clinical utility of on-demand multiplex respiratory pathogen testing among adult outpatients. J Clin Microbiol 54(12):2950 2955

19. Brittain-Long R, Westin J, Olofsson S, Lindh M, Andersson L-M (2010) Prospective evaluation of a novel multiplex real-time PCR assay for detection of fifteen respiratory pathogens - duration of symptoms significantly affects detection rate. J Clin Virol 47(3): 263-267

20. Jartti T, Lehtinen P, Vuorinen T, Koskenvuo M, Ruuskanen O (2004) Persistence of rhinovirus and enterovirus RNA after acute respiratory illness in children. J Med Virol 72(4):695-699

21. Wiemken T, Peyrani P, Bryant K, Kelley R, Summersgill J, Arnold F, Carrico R, McKinney W, Jonsson C, Carrico K (2013) Incidence of respiratory viruses in patients with community-acquired pneumonia admitted to the intensive care unit: results from the severe influenza pneumonia surveillance (SIPS) project. Eur J Clin Microbiol Infect Dis 32(5):705-710

22. Singer M, Deutschman CS, Seymour CW, Shankar-Hari M, Annane D, Bauer M, Bellomo R, Bernard GR, Chiche J-D, Coopersmith CM (2016) The third international consensus definitions for sepsis and septic shock (sepsis-3). JAMA 315(8):801-810

23. Edman-Wallér J, Ljungström L, Jacobsson G, Andersson R, Werner M (2016) Systemic symptoms predict presence or development of severe sepsis and septic shock. Infectious Diseases 48(3):209-214

24. Denis E, Martis N, Guillouet-de Salvador F, Demonchy E, Degand N, Carles K, Roger P-M (2016) Bacteraemic urinary tract infections 
may mimic respiratory infections: a nested case-control study. Eur J Clin Microbiol Infect Dis 35:1601-1605

25. Ljungström LR, Steinum O, Brink M, Gårdlund B, Martner J, Sjölin J (2011) Diagnostik och diagnoskodning av svår sepsis och septisk chock. ICD10 bör kompletteras med tilläggskoder Läkartidning en 108:276

26. Loens K, Van Heirstraeten L, Malhotra-Kumar S, Goossens H, Ieven M (2009) Optimal sampling sites and methods for detection of pathogens possibly causing community-acquired lower respiratory tract infections. J Clin Microbiol 47(1):21-31

27. Weinstein MP (2003) Blood culture contamination: persisting problems and partial progress. J Clin Microbiol 41(6):2275-2278

28. Falsey AR, Becker KL, Swinburne AJ, Nylen ES, Formica MA, Hennessey PA, Criddle MM, Peterson DR, Baran A, Walsh EE (2013) Bacterial complications of respiratory tract viral illness: a comprehensive evaluation. J Infect Dis 208(3):432-441

29. Boivin G, De Serres G, Hamelin M-E, Côté S, Argouin M, Tremblay G, Maranda-Aubut R, Sauvageau C, Ouakki M, Boulianne N (2007) An outbreak of severe respiratory tract infection due to human metapneumovirus in a long-term care facility. Clin Infect Dis 44(9):1152-1158

30. Strålin K, Törnqvist E, Kaltoft MS, Olcén P, Holmberg H (2006) Etiologic diagnosis of adult bacterial pneumonia by culture and
PCR applied to respiratory tract samples. J Clin Microbiol 44(2): 643-645

31. Bjarnason A, Lindh M, Westin J, Andersson L-M, Baldursson O, Kristinsson K, Gottfredsson M (2016) Utility of oropharyngeal real-time PCR for S. pneumoniae and $\mathrm{H}$. influenzae for diagnosis of pneumonia in adults. Eur J Clin Microbiol Infect Dis 36:529-536 $1-8$

32. Herberg JA, Kaforou M, Wright VJ, Shailes H, Eleftherohorinou H, Hoggart CJ, Cebey-López M, Carter MJ, Janes VA, Gormley S (2016) Diagnostic test accuracy of a 2-transcript host RNA signature for discriminating bacterial vs viral infection in febrile children. JAMA 316(8):835-845

33. Suarez NM, Bunsow E, Falsey AR, Walsh EE, Mejias A, Ramilo O (2015) Superiority of transcriptional profiling over procalcitonin for distinguishing bacterial from viral lower respiratory tract infections in hospitalized adults. J Infect Dis 212(2):213-222

34. Santolaya ME, Alvarez AM, Acuña M, Avilés CL, Salgado C, Tordecilla J, Varas M, Venegas M, Villarroel M, Zubieta M (2016) Efficacy and safety of withholding antimicrobial treatment in children with cancer, fever and neutropenia, with a demonstrated viral respiratory infection: a randomized clinical trial. Clin Microbiol Infect 23:173-178 